https://helda.helsinki.fi

\title{
The Weber Thesis and Economic Historians
}

\section{Peltonen, Matti}

Max Weber Studies Group

2008

Matti Peltonen, The Weber Thesis and Economic Historians, Max Weber Studies Vol. 8 No.

1 ( 2008)

http://hdl.handle.net/10138/9151

Downloaded from Helda, University of Helsinki institutional repository.

This is an electronic reprint of the original article.

This reprint may differ from the original in pagination and typographic detail.

Please cite the original version. 


\title{
The Weber Thesis and Economic Historians
}

\author{
Matti Peltonen
}

\begin{abstract}
One of the most exciting and most discussed economic theories is the one proposed by Max Weber in his essay The Protestant Ethic and the 'Spirit' of Capitalism (1904-1905). According to Weber, the Protestant ethic, a mode of behaviour whereby ascetic ways of life were motivated by Protestant theological ideas, had changed during the previous century into a 'spirit' of capitalism, a new lifestyle or ethos, in which hard work or accumulation could only be motivated with the most commonplace ideas about work and accumulation being their own rewards. Unfortunately, his argument was too complicated for his contemporary readers and was simplified along the lines of an older model to that of the theory which we nowadays recognize as the Weber Thesis. This simplified version claims that Protestant religion (or the Reformation) was the cause of (or at least the most suitable religion for) Western capitalism. For some reason this latter version, which has lost all contact with the historicity of Weber's concepts, has satisfied most social scientists. The case of economic historians is, however, quite different. The so-called Weber Thesis has been the target of criticism and protests from the ranks of economic historians throughout most the twentieth century. It is interesting to investigate how successful economic historians have been in their long durée criticism of the Weber Thesis and if they have succeeded in bringing into the open items originally included in Weber's own thought about the change from the Protestant ethic to the 'spirit' of capitalism. Especially interesting is whether economic historians have used the more historical categories already proposed by Weber instead of the more universal categories and concepts preferred by other social scientists. Furthermore, does the criticism of the Weber Thesis imply that economic historians have had a better idea of what Weber thought as compared with other social scientists? Recently, however, a more tolerant, even accepting, view of the Weber Thesis appears to have emerged within the economic historical literature. As well-known examples one could mention David Landes and Niall Ferguson, who have recently supported the idea that, because culture makes all the difference, also Weber's idea about religious attitudes as the catalyst for the rise of capitalism in the West should be given serious thought.
\end{abstract}

Keywords: capitalism and religion, economic historians, historicity of Weber's concepts, Protestant-ethic thesis. 


\section{Introduction: The Weber Thesis and its origins}

One of the most exciting and most discussed economic theories is the one proposed by Max Weber in his essay The Protestant Ethic and the 'Spirit' of Capitalism (1904-1905) published more than a hundred years ago. According to Weber, the Protestant ethic, a mode of behaviour whereby an ascetic way of life was motivated by Puritanistic theological ideas, had changed during the previous century into a 'spirit' of capitalism, a new lifestyle or ethos, in which hard work and accumulation was motivated with the most commonplace ideas about work or accumulation being their own rewards. Weber criticized this situation as the 'Iron Cage' of capitalism and lamented the loss of spirituality in modern life.

Unfortunately, Max Weber's argument was too complicated for the contemporary Western mind and his views were simplified along the lines of an older model to that of the theory which we nowadays recognize as the Weber Thesis. This simplified version claims that Protestant religion (or the Reformation) was the cause of (or at least the most suitable religion for) Western capitalism. This idea had been popular since at least the eighteenth century. This interpretation of the essay also leaves Weber's concept of the spirit of capitalism in an awkward position: either it is thought to be redundant or it is given as a synonym for capitalism. Several readers of the essay give the spirit of capitalism as the cause of capitalism in the West. In contemporary German discussion concerning the nature of modern capitalism, such ideas about the connection between Protestantism and capitalism were proposed, for instance, by the social historian Eberhard Gothein and the economist or economic historian Werner Sombart. ${ }^{1}$ Weber's essay on the Protestant ethic was, to a considerable degree, a criticism of the way his friend Werner Sombart used the concept of the spirit of capitalism. For some reason this simplified version of the Weber Thesis, which has lost all contact with the historicity of Weber's concepts, has satisfied the intellectual curiosity

1. Friedemann Voigt, 'Vorbilder und Gegenbilder. Zur Konzeptualisierung der Kulturbedeutung der Religion bei Gothein, Sombart, Simmel, Jellinek, Weber and Troeltsch', in Wolfgang Schluchter and Friedrich Wilhelm Graf (eds.), Asketischer Protestantismus und der 'Geist' des Kapitalismus Max Weber und Ernst Troeltsch (Tübingen: Mohr Siebeck, 2005), pp. 155-84. The early history of the Weber Thesis is also discussed in several interesting essays in Hartmut Lehmann and Guenther Roth (eds.), Weber's Protestant Ethic: Origins, Evidence, Contexts (Cambridge: Cambridge University Press, 1995). 
of most social scientists. Especially sociologists have recognized Weber's essay in the post-war era as an eminent classic in their field and regard the Weber Thesis as his crowning achievement. The case of economic historians is, however, quite different.

\section{Economic historians criticize the Weber Thesis:}

The Tawney years - the 1920s and 1930s

The so-called Weber Thesis has been the target of criticism from the ranks of economic and social historians throughout most of the twentieth century. This criticism that was initiated by R.H. Tawney's famous study Religion and the Rise of Capitalism in the 1920s became quite widespread during the 1920s and 1930s. Tawney's book was an instant success and sold astonishingly well during the following decades. ${ }^{2}$ It was immediately translated into several languages (French, German, Japanese, Spanish, Italian, Polish and Dutch). ${ }^{3}$ It can be said that Tawney made Weber famous outside Germany and kept alive the reputation of his essay on the Protestant ethic. At first, however, Tawney understood Weber's ideas in the same way as the contemporary German reception. In an extensive note at the end of his book, Tawney summarized the criticism levelled against the essay into three points.

2. Of Tawney's career, see Ross Terrill, R.H. Tawney and His Times: Socialism as Fellowship (Cambridge, MA: Harvard University Press, 1973); Anthony Wright, R.H. Tawney: Life on the Left (Manchester: Manchester University Press, 1897); David Ormrod, 'R. H. Tawney and the Origins of Capitalism', History Workshop 18 (1984), pp. 138-59 and John Kenyon, The History Men: The Historical Profession in England since the Renaissance (London: Weidenfeld \& Nicolson, 1983).

3. Terrill, R.H. Tawney, p. 59. Another important work which shifted opinions on the Weber Thesis in this direction was Werner Sombart's Der Bourgeois. Zur Geistesgeschichte des modernen Wirtschaftsmenschen (1913), which he wrote to meet the criticism of Weber's essay concerning his use of the concept the spirit of capitalism and which was quickly translated, for instance, into English (1915), Swedish (1916) and French (1926). Another hugely successful essay by Werner Sombart was Die Juden (1911), which was immediately translated into English by a Jewish economic historian R. Epstain (1915). See the highly informative article on Sombart's essay by Natalie Zemon Davis, 'Religion and Capitalism Once Again? Jewish Merchant Culture in the Seventeenth Century. (A Preliminary Inquiry)', in Jeremy Adelman and Stephen Aron (eds.), Trading Cultures: The Worlds of Western Merchants. Essays on Authority, Objectivity, and Evidence (Publications of the Shelby Cullom Davis Center for Historical Studies, Princeton University; Turnholt: Brebols, 2001), pp. 59-88. In his essay Sombart tried to show that the Puritan quality of Protestant movements was inherited from the Jews. Soon afterwards, however, Sombart wrote several other essays suggesting that, for instance, luxury and wars were important sources for the rise of capitalism. 
First, Tawney wrote in his criticism of Weber's essay that Weber did not pay enough attention to the fact that the early industrial development in England and Holland was caused by new powerful economic movements, followed only thereafter by psychological changes. This criticism did not in any way, of course, meet Weber's original thesis about the relationship between Protestant ethic and the spirit of capitalism. Second, Tawney claimed that Weber touched too lightly on intellectual movements outside the Reformation which also played a role in the rise of capitalism. Tawney did not realise that Weber did not at all state that the Reformation as an intellectual movement gave rise to new economic institutions, so this part of Tawney's criticism also misfired. Third, Tawney reproached Weber for his misunderstanding of Calvinism and claimed quite rightly that especially the early phases of Calvinism were very hostile to successes in business life. Tawney did not take into account that Weber had expressed the same view in quite strong wording at the beginning of his essay. So this criticism, too, left untouched the hypothesis Weber was actually stating. Tawney's points were reminiscent of the German discussion concerning the impact of Protestantism on capitalism, and Weber had reacted several times to similar accusations and criticisms during the years 1907-1910 in the journal Archiv für Sozialwissenschaft und Sozialpolitik. ${ }^{4}$

In his preface to the second edition of Religion and the Rise of Capitalism (the Penguin edition published in 1938 and still in print) Tawney, however, took back his critical remarks without erasing the unfortunate end note of the first edition. During the twelve years that had passed since the publication of his monograph Tawney had had time to read Weber more carefully. During this time, he wrote prefaces to English translations of two of Weber's works and probably learned more about Weber's own thinking. In 1927, Tawney wrote a preface to General Economic History, translated by Frank Knight, and three years later wrote another preface to Talcott Parsons's translation of Weber's Protestant Ethic essay. Parsons had been Tawney's student for one semester at the London School of Economics and Tawney had instructed him to continue his studies in Heidelberg.

The huge popularity of Tawney's Religion and the Rise of Capitalism was instigated by his exceptionally beautiful writing, his harsh

4. The German discussion of Weber's original 1904-1905 essay has now been translated and published in David J. Chalcraft and Austin Harrington (eds.), The Protestant Ethic Debate: Max Weber's Replies to his Critics, 1907-1910 (Liverpool: Liverpool University Press, 2001). 
criticism of the evils of capitalism and of the unengaging attitude of the contemporary religious organizations. Still after half a century following the original publication of Tawney's work, one of the more conservative constitutional historians in Britain condemned the book as the most damaging text thrown at the face of the British and the Western establishment, a text that was able to corrupt the best generations (of historians) of the twentieth century. ${ }^{5}$

In Tawney's own words, his idea on the connection between Protestant ethic and capitalist business life seems to be such that the concept of a specific 'spirit of capitalism' becomes redundant:

History is a stage where forces which are within human control contend and cooperate with forces which are not. The change of opinion described in these pages drew nourishment from both. The storm and fury of the Puritan revolution had been followed by a dazzling outburst of economic enterprise, and the transformation of the material environment prepared an atmosphere in which a judicious moderation seemed the voice at once of the truest wisdom and the sincerest piety. But the inner world was in motion as well as the outer. The march of external progress woke sympathetic echoes in hearts already attuned to applaud its triumph, and there was no consciousness of an acute tension between the claims of religion and the glittering allurements of a commercial civilization, such as had tormented the age of the Reformation. ${ }^{6}$

For Tawney's version of the Weber Thesis, the violent history of the Reformation in England (he wrote of the abolition of monasteries and schools in the same manner as Karl Marx in Das Kapital described what he called the primitive accumulation) and the cruelties of the Civil War during the 20 years 1640-1660 gave the English Puritans a rough character and, together with the simultaneously growing

5. This dissatisfaction with R.H. Tawney was expressed by G.R. Elton, in fact several times, for instance in his inaugural lecture in 1968 (later published in his Return to Essentials [Cambridge: Cambridge University Press, 1991], pp. 85-86) and later in an essay in Times Literary Supplement, 11 February 1977. Originally Elton offered his opinion in Reformation Europe 1517-1559 (London: Fontana, 1963), p. 315. In the next generation of historians, the intellectual historian Christopher Hill was probably one of those most visibly influenced by Tawney. Hill used the concept Protestant ethic in a manner of his own making it the synonym for the spirit of capitalism which went totally against the grain of Weber's ideas on these phenomena. See, for instance, Christopher Hill, The World Turned Upside Down: Radical Ideas during the English Revolution (London: Maurice Temple Smith, 1972), especially chapter 16.1 on 'The Protestant Ethic'.

6. R.H. Tawney, Religion and the Rise of Capitalism: A Historical Study (Harmondsworth: Pelican, 1938), p. 274. 
Atlantic commerce, made it easier to separate matters of religion and business from one another. This kind of reasoning was, of course, a long way off from Weber's original ideas. ${ }^{7}$ Later on, for instance in the lectures he gave in Denmark and Sweden at the beginning of the 1950s, Tawney emphasized the long-term influence of the popular culture of the Reformation period on the formation of democratic institutions in Britain:

The tone of the astonishing flood of cheap pamphlets which pour from the press; the outburst of indignation in London against ecclesiastical dignitaries; the visions and revelations discussed on by troopers in the new Model army; the proliferation of every type of sect, show that popular culture is predominantly a religious culture. Its exponents, now that that at last they have found their voice, are in one sense or another Puritan; but they do not mean by Puritanism what their betters mean. They hate, not only bishops, but any forms of coercive church. Their demand is, not for the ecclesiastical discipline established in Scotland, with its inquisitions, censures, and penalties on backsliders, but for the complete separation of Church and State, Liberty for the individual conscience, and equal tolerance for all religious groups, is their central aim. Once formidable, such aspirations...to the religious sphere. Defeated, in their own day, it is in them, not in economic discontent, that the origins of English democracy are to be sought. ${ }^{8}$

R.H. Tawney's Religion and the Rise of Capitalism created a model for younger scholars, who followed him in testing the data from countries other than England, on whether the economic doctrines of national Puritanist movements were beneficial or harmful for the development of capitalist economic institutions. The result was, without exception, the same as Weber's: Puritans were even more hostile to capitalism than Catholics. These imitations of Tawney's book include, for instance, H.M. Robertson's The Rise of Economic Individualism (1933), W.F. van Gunsteren's Kalvinismus und

7. It is interesting to note that at least during the 1930s Talcott Parsons was very well aware of the difference between Weber's ideas and the so-called Weber Thesis. For instance, when criticizing H.M. Robertson's book (see n. 9) he stated that Weber's essay "was not a general theory of the "cause" of modern capitalism in the least', and that Robertson (and hence also R.H. Tawney) had misinterpreted Weber's ideas of the relationship between (economic) individualism and capitalism. Talcott Parsons, 'H.M. Robertson on Max Weber and his School', Journal of Political Economy 43 (1935), pp. 688-96.

8. R.H. Tawney's lectures in Denmark and Sweden in October-November 1951, The Tawney Papers 6:7 (Lecture III, version C), British Library of Political and Economic Science, London School of Economics. 
Kapitalismus. Ein Beitrag zur Erkenntnis der Beziehungen zwischen kalvinistischer Sozial-Ethik und kapitalistischem Wirtschaftsgeist (1934) and Wolmar Clemmensen's De religiöse systemers indlfytelse paa de ehrvervsetiske princippers udvikling $i$ Danmark (1940). ${ }^{9}$ So powerful was the influence of Tawney's book that all these works also had to conclude that Weber had mistaken and exaggerated the transforming power of religious ideas, while economic and political forces so clearly were more important in the birth of modern economic institutions.

H.M. Robertson's The Rise of Individualism (1933) was at least partly written against Tawney's ideas. For Tawney, capitalism was something to be criticized and the economic elite to be despised, but for Robertson it was the other way round. He did not approve of Weber's tone, where he detected a critical attitude reminding him of Marxist ideas on capitalism. The growth of capitalism was for Robertson a 'natural' outcome, there could have been no evil force such as the spirit of capitalism at its root. So Robertson seemed to have produced a totally unique reading of Weber, where Puritanism first creates the 'spirit of capitalism', which for him functions as the synonym for 'the rise of individualism', which then creates the capitalist economy. However, many other readings of Weber's essay leave the concept of the spirit of capitalism redundant or understand it as a synonym for the concept of capitalism as an economic system. Robertson tried to include the concept of the spirit of capitalism in a meaningful way in the Weber Thesis-type of interpretation on Weber's thinking.

These 1930s monographs on the Weber Thesis were accompanied by several textbooks on the economic history of Europe, where the Weber Thesis was commented upon and criticized. These works include Economic History of Europe (1927-1929) by Melvin M. Knight, Harry Elmer Barner and Felix Flügel, Economic History of Europe (1936) by Herbert Heaton and Economic History of Europe (1941) by Shepard Bancroft Clough and Charles Woolsey Cole.

9. H.M. Robertson, Aspects of the Rise of Economic Individualism: A Critique of Max Weber and His School (Cambridge: Cambridge University Press, 1933); W.F. Van Gunsteren, Kalvinismus und Kapitalismus. Ein Beitrag zur Erkenntnis der Beziehungen zwischen kalvinistischer Sozial-Ethik und kapitalistischem Wirtschaftsgeist (Amsterdam: N.V. Noord-Hollandsche Uitgeversmaatschappig, 1934); Wolmer Clemmensen, De religiöse systemers indlfytelse paa de ehrvervsetiske princippers udvickling i Danmark. Fra reformationen indtil det nittende aarhundredes begyndelse (Kjöbenhavn: Nyt Nordisk Forlag Arnold Busch, 1940). 
There seems to have been nearly complete agreement among economic historians that the Weber Thesis was totally mistaken. ${ }^{10}$ In formulating their opinion in this manner economic historians were, of course, right and Weber could not have agreed with them more. Unwittingly the economic historians of the 1920s and 1930s only reinforced Weber's case without realizing it. It seems that most historians read about the Weber Thesis from second-hand sources, and even those who had seen Weber's texts, trusted more the contemporary German and British (especially Tawney's) interpretations of Weber's ideas. There were, however, some voices that also found something positive in his hypothesis and, for instance, mentioned cases where some innovators or remarkable entrepreneurs in the early phases of the Industrial Revolution were known to be from a family with Puritan leanings. ${ }^{11}$

An interesting study to be read along with those directly commenting on Weber and Tawney is Bernard Groethuysen's Origines de l'spirit bourgeois en France (1927), which could be defined as a continuation of Weber's essay. ${ }^{12}$ Groethuysen was originally a German scholar, who had specialized in French intellectual history of the Enlightenment period. He gives the outlines of a bourgeois worldview that takes distance from the teachings of the Catholic Church and, little by little, develops into an independent habitus during the eighteenth century, becoming a conscious class-based life-style. Groethuysen's book could be compared in some respects to the early

10. There is, however, at least one notable exception among economic historians, the famous Swedish economic historian Eli F. Heckscher, who, several times during the 1930s and 1940s, expressed his positive view of Weber's thinking. See, for instance, his Ekonomisk-historista studier (Stockholm: Bonniers, 1936), p. 13. Heckscher thought that, after Marx, Weber was the first real talent among German social scientists. Heckscher appreciated Weber for his investigations of 'a changing mentality' in economic studies. In his Historieuppfattning. Materialistisk och annan (Stockholm: Bonniers, 1944), pp. 19-20, he made it clear, moreover, that he saw Weber as a counterweight to historical materialism. In both texts Heckscher mentioned R.H. Tawney and probably interpreted Weber through Tawney's Religion and the Rise of Capitalism in a way that omits its criticism levelled against Weber's essay.

11. Tawney's pupil Margaret James, in her Social Problems and Policy during the Puritan Revolution 1640-1660 (London: George Routledge \& Sons, 1930), wrote the first of such studies.

12. This French publication, like its English translation, is a condensed version of the original German work published in two volumes also in 1927 as Die Entstehung der bürgerliche Welt- und Lebensanschauung in Frankreich (Halle 1927). See also R.R. Palmer, Catholics and Unbelievers in Eighteenth Century France (Princeton, NJ: Princeton University Press, 1939) as a work inspired by Groethuysen's monograph. 
work of Norbert Elias. The deficiency in Groethuysen's analysis is, when compared to Weber's ideas, that he only considered this new life-style as a middle-class phenomenon and excluded lower orders from his picture. For Weber, however, the spirit of capitalism was also the mentality of the workers. ${ }^{13}$

\section{The Cold War period (the 1940s to 1980s)}

\subsection{Sociology gets a new father}

After the Second World War the status of Max Weber changed in a remarkable way. Scholars working in social sciences began to see him as a sociologist, whereby his background as a leading member of the younger generation of economists in the German 'historical school' was almost forgotten. During this period, the work of Talcott Parsons and his pupils, for instance Robert K. Merton and Robert N. Bellah, especially influenced the way Weber was assessed. ${ }^{14}$ Also during this period, the Protestant Ethic essay remained essential to Weber's growing reputation. The new thing was the emphasis on how right Weber had been. In spite of the work of economic and religious historians to the contrary, sociologists were convinced that Weber had been, in the end, or when considering the bigger picture, or in the light of later developments, right against all petty-minded and misplaced criticism.

One could cite S.N. Eisenstadt's thoughts as an example of how to give a new interpretation of the Weber Thesis. ${ }^{15}$ Writing in the 1960s Eisenstadt told his readers that the older version of the Weber Thesis had now been discovered as being inadequate, since more and more of Weber's texts had become familiar to English-speaking scholars. Now it was clear that the Protestant economic ethic was quite hostile to modern lifestyles. What new translations of Weber's studies had

13. For Weber's references to the 'view from below' (the worker's point of view of the 'spirit' of capitalism), see Max Weber, Die protestantischen Ethik und die 'Geist' des Kapitalismus (Weinheim: Belitz Athenäem, 3rd edn, 2000), pp. 16-17, 19, 22 and 151.

14. Robert K. Merton, 'Science, Technology, and Society in Seventeenth-century England', Osiris 4 (1938), pp. 360-632; Robert N. Bellah's Tokugawa Religion: The Values of Pre-Industrial Japan (Glencoe: The Free Press, 1957).

15. S.N. Eisenstadt, 'The Implication of Weber's Sociology of Religion for Understanding Processes of Change in Contemporary Non-European Societies and Civilizations', in Charles Y. Glock and Phillip E. Hammond (eds.), Beyond the Classics? Essays in the Scientific Study of Religion (New York: Harper \& Row, 1973), pp. $131-80$. 
to do with this revelation was left quite unacknowledged. The readers of the original 1904-1905 essay know, of course, that this was Weber's starting point from the beginning. But Eisenstadt continued by asserting that there is a new consensus according to which this severe asceticism perhaps applied only to the early history of Puritan religious movements and that perhaps the later phases of their development were more relaxed. In this way, the original Weber Thesis which, after the Second World War, had become the model for a very important body of social science reasoning, the modernization theory, could be saved to fulfil its role in the intellectual climate of the Cold War. Another aspect of this important role attached to Weber and his essay concerned itself with fighting back the doctrines of historical materialism and the growing interest in Karl Marx's work. ${ }^{16}$ During the Cold War period, the difference between critical (economic) historians and accepting sociologists in assessing the merit of the Weber Thesis was at its broadest extent.

\subsection{Economic historians assess the Weber Thesis}

Soon after the war, we also meet some economic historians, who, either on their own initiative or in co-operation with Parsonian sociology, developed ideas of the Industrial Revolution into theories of economic growth and social modernization. Here one can mention, for instance, T.S. Ashton and W.W. Rostow as historians who accepted and used the Weber Thesis. ${ }^{17}$ Ashton preferred a commonsensical identification of religious dissenters as potential entrepreneurs and industrial innovators. ${ }^{18}$ For him 'the industrial revolution was also a

16. Even now, at the beginning of the 2000s, Weber's essay is marketed both in the USA and in Germany as a refutation of Marx's ideas about the materialist interpretation of history. See the back cover text of, for instance, the Belts Athenäum edition of the essay. "Seine Studie "Die protestantische Ethic" ist berühmt geworden als Gegenposition zur Marxschen Geschichtstheorie' (3rd edn, 2000). The Penguin Classics edition of the essay says on its back cover: 'Max Weber opposes the Marxist concept of dialectical materialism and relates the rise of capitalist economy to the Calvinist belief in the moral value of hard work...' This edition was first published in 2002. Clearly, these views are not shared by the editors of these versions of Weber's essay.

17. T.S. Ashton, The Industrial Revolution 1760-1830 (Oxford: Oxford University Press, 1948); W.W. Rostow, The Process of Economic Growth (Oxford: Clarendon Press, 1953).

18. I think Ashton can only be referring to Tawney when he wrote that "The idea that, somehow or other, men had become self-centred, avaricious, and anti-social is the strangest of all the legends by which the story of the industrial revolution has been obscured'. Ashton, Industrial Revolution, p. 102. 
revolution of ideas' implying that the broadened worldviews and a more advanced stage of science and general education of at least the commercial classes were needed as preconditions for this important transformation of modern society. Ashton was also clearly hostile to Tawney's ideas and carefully avoided mentioning his name. Rostow's 1953 book, The Process of Economic Growth, is preparation for his theory of stages of economic growth, which was meant as a substitute for the theory of social development of historical materialism. Here he refers openly to Max Weber and R.H. Tawney as sources of inspiration to his theorizing.

History affords cases when the balance of ideas and values effectively operative in a society appear to change rapidly, e.g. in the decade of the 1960s in the United States, in France as a result of the revolution, in Japan as a result of its opening to the Western World and its internal revolution of the late 1960 's; in Russia as a result of the revolution; and in modern Turkey, Israel, Pakistan, \& c. ${ }^{19}$

Rostow, however, admitted in 1953 that he had not yet figured out what his 'general theory of society' would look like. Instead he gave a synchronous list of propensities, among which were, for instance, 'the propensity to develop fundamental science; to apply science to economic ends: to accept the possibilities of innovation; to seek material advance; to consume; and to have children' ${ }^{20}$ He never revealed to his readers whose propensities these were and how they had come to his attention, but it seems that he had adopted some kind of methodological individualism, so that the propensities can refer both to the society as a whole and to the individuals or families that make up that society as its members. Later on these propensities develop into main characteristics of the successive stages of economic growth with the exception of the propensity to have children which disappears from Rostow's theory of modernization of society. ${ }^{21}$

W.W. Rostow and T.S. Ashton were, however, exceptions among the great multitude of economic historians. The majority of them remained hostile towards the Weber Thesis even after the Second World War. An interesting example is the textbook written by Everett E. Hagen, On the Theory of Social Change: How Economic Growth Begins (1962), which stated boldly that 'association of material

19. Rostow, Process of Economic Growth, p. 44.

20. Rostow, Process of Economic Growth, p. 21.

21. W.W. Rostow, Stages of Economic Growth (Cambridge: Cambridge University Press, 1960). At this stage Rostow did nor refer any more to Tawney and Weber as sources of inspiration for his theory. 
progress with the Puritan dogma is no longer persuasive' (p. 17) and 'the doctrine that the specific religious dogma of the Puritan dissenter is peculiarly associated with innovational activity is obsolete' (p. 93). There are also many economic historians who continued the example of R.H. Tawney and published critical assessments of the Weber Thesis. The most notable of these are Jelle C. Riemersma's Religious Factors in Early Dutch Capitalism 1550-1650 (1967), which was based on a dissertation presented in 1955 at the University of California and Kurt Samuelsson's Ekonomi och religion (1957, English translation Religion and Economic Action 1961). ${ }^{22}$ Riemersma cannot help but to conclude that Dutch Calvinism was also quite traditional in its economic doctrines and consequently quite hostile to modernizing economic institutions. For him, too, economic and political factors were of prime importance in the development of early Dutch capitalism. Riemersma has read Weber's texts carefully and reports many aspects of Weber's thought that contradict the Weber Thesis and, also, his own results.

Samuelson's essay is a summing up of all previous critical views expressed by economic historians against the Weber Thesis. It has been astonishingly successful. It has been, for instance, translated into English, French, Spanish and Japanese. Furthermore, due to these translations, it is quite often referred to in discussions of the Weber Thesis and even one chapter of Samuelsson's essay has been included in the Weber Thesis Reader edited by Robert W. Green. ${ }^{23}$ There is also a very perceptive criticism of Samuelsson's essay by the church historian Edmund Morgan. This review is one of those, usually soon-forgotten contributions to the Weber Thesis discussion which tries to steer the discussion in a more adequate direction regarding Weber's original attempts with his essay. ${ }^{24}$

22. Jelle C. Riemersma, Religious Factors in Early Dutch Capitalism 1550-1650 (Studies in the Social Sciences, 2; The Hague and Paris: Mouton, 1967); Kurt Samuelsson, Religion and Economic Action: The Protestant Ethic, the Rise of Capitalism, and the Abuses of Scholarship (Toronto: University of Toronto Press, 1993 [1961]).

23. Kurt Samuelsson, 'Religion and Economic Action', in Robert W. Green (ed.), Protestantism, Capitalism, and Social Science: The Weber Thesis Controversy (Lexington, Toronto and London: Heath, 1973), pp. 137-49.

24. Edmund S. Morgan in The William and Mary Quarterly, 3rd series, 20(1) (January 1963), pp. 135-40. Another early text gently criticizing the Weber Thesis interpretation of Weber's essay is an article by Ephraim Fischoff, 'The Protestant Ethic and the Spirit of Capitalism: The History of a Controversy', Social Research 11 (1944), pp. 61-77. This essay was later included in the first reader on the Weber Thesis discussion, Robert W. Green (ed.), Protestantism and Capitalism: The Weber Thesis and 
3.3. Problems in the economic historians' reception of the Protestant-ethic essay

Kurt Samuelsson's Ekonomi och religion (1957) does not only summarize all possible criticism ever levelled against Weber's essay, it also clearly exhibits the problems that have been common in this ongoing discussion about the Weber Thesis. First, Samuelsson regards, as do most of the readers of Weber's essay (especially those who read it as a translation in another language), both the Protestant ethic and the spirit of capitalism as ideas, doctrines, or attitudes. Second, Samuelsson is unable to make the distinction between capitalism and the spirit of capitalism. Furthermore, he accuses Weber of not being able to make a clear conceptual difference between them. This is not a common mistake to make, because it is more usual to think that, if the Protestant ethic did not create capitalism then the spirit of capitalism did. Third, Samuelsson only discusses the spirit of capitalism as an entrepreneurial mentality, something that refers to 'industrikaptener' (captains of industry), but has nothing to do with the lower orders, or people like workers, who were so important to Weber.

Several well-known economic historians commented on the Weber Thesis during the period of the Cold War. A short but unusually clear-headed description of Weber's essay was provided by David Landes in his The Unbound Prometheus (1972), although the issue concerning the impact of changing lifestyles on modern capitalism did not play any significant role in his work. ${ }^{25} \mathrm{~A}$ more negative view of the Weber Thesis was given by Andre Gunder Frank in his Dependent Accumulation and Underdevelopment (1979). Frank shows, by citing several of Weber's own texts, that the Weber Thesis cannot be a reliable description of the course of history. He does not seem to realize that by doing so he also proves that one cannot find the Weber Thesis in Weber's own texts. A popular textbook of economic history during this period, Dudley Dillard's Economic Development of the North Atlantic Community (1967), gives

its Critics (Boston: Heath, 1959), pp. 107-14. Green warns the readers of Fischoff's article that they 'may be somewhat surprised at the careful qualifications Fischoff draws around the Weber thesis' thus implying that he was not reliable, despite his 'unusually judicious appraisal' of the evidence, conclusion and methods of various writers.

25. David S. Landes, The Unbound Prometheus: Technological Change in Western Europe from 1750 to the Present (Cambridge: Cambridge University Press, 1972), pp. $22-24$. 
an extended overview of the Weber Thesis controversy, relying chiefly on Kurt Samuelsson's essay. ${ }^{26}$

\subsection{E.P. Thompson and the Methodist working class}

E.P. Thompson is not usually considered in connection with Weber studies, only church historians who have specialized in the history of British or American Methodism comment on his ideas in The Making of the English Working Class (1963). Even those who have written essays on Thompson have hesitated to approach this aspect of his work. ${ }^{27}$ It is obvious that E.P. Thompson is one of those historians whose admiration of R.H. Tawney greatly irritated G.R. Elton to loose his temper on so many occasions. Even Thompson's and Tawney's careers seem a bit parallel at several points (career in adult education, participation in popular movements, writing scholarly works as well as popular texts like pamphlets).

R.H. Tawney must have also been important to Thompson when applying Weber to this important study, because most of the references to Weber's essay also include Tawney's book in the same note. In spite of this, however, Thompson manages to create a completely new approach to the relationship between religious movements and industrial society when compared to previous discussions of the Weber Thesis. ${ }^{28}$ In fact, Thompson thought he could criticize both Weber and Tawney on the point that they had only considered the Protestant ethic (and the spirit of capitalism) as entrepreneurial mentalities. Although this criticism does not apply to Weber, it is a very good point and takes the discussion closer to the original Weber essay. ${ }^{29}$

26. Dudley Dillard, Economic Development of the North Atlantic Community: Historical Introduction to Modern Economics (Englewood Cliff: Prentice \& Hall, 1967), pp. 87-91.

27. Thompson's relationship to Weber (and Tawney) is not mentioned by Perry Anderson or Bryan Palmer. See Perry Anderson, Arguments within English Marxism (London: Verso, 1980) and Bryan D. Palmer, E.P. Thompson: Objections and Oppositions (London: Verso, 1994). The exception is Harvey K. Kaye, The British Marxist Historians: An Introductory Analysis (Cambridge: Polity Press, 1984), pp. 193-94.

28. E.P. Thompson, The Making of the English Working Class (London: Gollancz, 1963). In the 1968 Penguin edition Thompson comes back to this question and answers some of his critics.

29. Some of Thompson's expressions like 'ritualised form of psychic masturbation', 'chiliasm of despair' or 'religious terrorism' to characterize Methodism have caused anxiety among historians of religion. 


\begin{abstract}
Puritanism contributed to the psychic energy and social coherence of middle-class groups which felt themselves to be 'called' or 'elected' and which were engaged (with some success) in acquisitive pursuits. How then should such a religion appeal to the forming proletariat in a period of exceptional hardship, whose multitudes did not dispose them to any sense of group calling, whose experiences at work and in their communities favoured collectivist rather than individualist values, and whose frugality, discipline or acquisitive virtues brought profit to their masters rather than success to themselves? $?^{30}$
\end{abstract}

Thompson's question about the double role of Methodism during the Industrial Revolution has inspired much new research, but unfortunately many of his commentators have concentrated on his expressions and use of language. ${ }^{31}$ The question of the role of Methodism has been discussed for the most part in connection with the so-called Halévy Thesis (Did Methodism save Great Britain from revolutionary upheaval during the French Revolution?), and very few have noted the relevance of Weber's essay. But, in effect, Thompson began investigating the same question that had interested Weber, the question of how, for the English proletarians in Thompson's case, the Protestant ethic became the spirit of capitalism. It is clear that Thompson runs out of adequate concepts nearly as soon as he starts his investigation. The only concept inherited from Weber that is in frequent use is 'work-discipline'.$^{32}$ There are 17 references, many of them several pages long, to work-discipline in The Making of the English Working Class. A few years later he wrote a separate essay on the birth of the industrial work-discipline. ${ }^{33}$

30. Thompson, Making of the English Working Class, pp. 391-92.

31. Theoretical or historiographical comments on Thompson's question concerning the role of Methodism for the early industrial working class include Alan D. Gilbert, 'Religion and Political Stability in Early Industrial England', in Patrick K. O'Brien and Roland Quinault (eds.), The Industrial Revolution and British Society (Cambridge: Cambridge University Press, 1993), pp. 79-99; James E. Bradley, Religion, Revolution and English Radicalism: Non-conformity in Eighteenth-Century Politics and Society (Cambridge: Cambridge University Press, 1990); David Hampton, The Religion of the People: Methodism and Popular Religion c. 1750-1900 (London: Routledge, 1996); Dee E. Andrews, The Methodists and Revolutionary America, 1760-1800 (Princeton, NJ: Princeton University Press, 2000).

32. Thompson, Making of the English Working Class, p. 392.

33. E.P. Thompson, 'Time, Work-Discipline and Industrial Capitalism', in E.P. Thompson, Customs in Common: Studies in Traditional Popular Culture (New York: The New Press, 1991), pp. 352-403. This essay was first published in Past E Present 38 (December 1967). 
But in terms of the social process we may suppose something like an oscillation, with religious revivalism at the negative and radical politics (tinged with revolutionary millenarianism) at the positive pole. The connecting notion is always that of the 'Children of Israel'. At one pole, the chiliasm of despair could reduce the Methodist working man to one of the most abject human beings... One the other hand, as if to baffle expectation, Methodist working men, and, indeed, local preachers, repeatedly emerged in the nineteenth century - in handfuls here and there - as active workers in different fields of working class politics. There were a few Methodist Jacobins, more Methodist Luddites, many Methodist weavers demonstrating at Peterloo, Methodist trade unionist and Chartists. ${ }^{34}$

Thompson's own answer to the question how Methodism could be so important to the early industrial working class in Britain includes three aspects, the aggressive indoctrination which was addressed especially to children in Methodist Sunday schools, the sense of community that Methodist congregations could give to their members during a difficult period of poverty and violence and the emotionally consoling effect of the religious practices of the Methodist Church during the worst years of the industrial revolutions (religious practices used as opiates in a more literal sense than suggested in the famous Marxist slogan). ${ }^{35}$

\section{Economic historians accept the Weber Thesis:}

The 1990s and after

In the 1990s an important change occurred in the attitude of many economic historians, especially in the United States, towards the Weber Thesis. Now, after several decades of resolute criticism, a considerable crowd of economic historians began signalling their approval of the idea that religious ideas can be important causes for the development of new economic institutions as well as a stimulus to economic growth. Stanley Engerman in his recent appraisal of

34. Thompson, Making of the English Working Class, pp. 429-30.

35. Thompson, Making of the English Working Class, pp. 412-19. Thompson's result comes quite close to an earlier investigation which is not usually mentioned in this context. I am referring to Robert F. Wearmouth's Methodism and the Common People of the Eighteenth Century (London: The Epworth Press, 1945), where the section 'What Methodism Did for the Common People' comprises the chapters 'It made religion live', 'Methodism gave opportunity', and 'Methodism developed responsibility, discipline and loyalty'. Thompson himself did not refer to Wearmouth's 1945 study in his works. 
Weber as an economist and economic historian criticized economic historians of the previous decades for their neglect of Weber's important contribution:

Rather curious, however, is that several of these recent works by economic historians do not refer to Weber's work on the Protestant ethic, and in those that do his work is not seen as central to explaining the rise of the west. Nevertheless, it is clear that as long as there is a belief that the economic performance of Western Europe has been unique, Weber has presented an argument that must be confronted. ${ }^{36}$

Engerman, however, is not alone in this new appreciation of the Weber Thesis. Concerning the history of New England before the Revolution of 1776 in America, Stephen Innis, (in his Creating the Commonwealth: The Economic Culture of Puritan New England, 1995), developed the thesis that the early colonists, despite their 'tortured attempts' could not prevent the Protestant ethic from becoming the spirit of capitalism. ${ }^{37}$ Similarly, Liah Greenfeld in her The Spirit of Capitalism: Nationalism and Economic Growth (2001) uses the Weber Thesis in an analogical way to make the claim that nationalism is to capitalist development and economic growth as Puritanism had been at an earlier stage. ${ }^{38}$

During a time when coercive forms of labor mobilization such as slavery and indentured servitude were taking root elsewhere in British America, New England's Puritans relied on the inner compulsions of worldly asceticism. ${ }^{39}$

In these contributions one can detect a more or less clearly stated return of modernization theory of the 1950s and 1960s also in the theoretical repertoire of economic historians. ${ }^{40}$

36. Stanley L. Engerman, 'Max Weber as Economist and Economic Historian', in Stephen Turner (ed.), The Cambridge Companion to Weber (Cambridge: Cambridge University Press, 2000), p. 264. Similar reproach on economic historians has been expressed recently by Phillip Benedict in his 'Max Weber on Calvinism, Society, and the State: A Critical Appraisal in Light of Recent Historical Research', in Hartmut Lehmann and Jean Martin Ouédraogo (eds.), Max Webers Religionssoziologie in interkultureller Perspektive (Göttingen: Vanderhoeck \& Ruprecht, 2003), p. 243.

37. Stephen Innis, Creating the Commonwealth: The Economic Culture of Puritan New England (New York and London: W.W. North, 1995), p. 312.

38. Liah Greenfeld, The Spirit of Capitalism: Nationalism and Economic Growth (Cambridge, MA and London: Harvard University Press, 2001).

39. Innis, Creating the Commonwealth, p. 125.

40. The return of modernization theory is described in a critical way by Harry Harootunian, The Empire's New Clothes: Paradigm Lost, and Regained (Chicago: Prickly Paradigm Press, 2004). 
There are also other well-known economic historians who are now remarking on the work of Max Weber in a favourable way. One of the most famous among them is David S. Landes, who already in his earlier work referred to Weber's essay. In his more recent The Wealth and Poverty of the Nations (1998), Landes surrenders to Weber and concludes as if expressing a novel view of economic life: 'If we learn anything from the history of economic development, it is that culture makes all the difference. (Here Max Weber was right on.) ${ }^{\prime 41}$ It is, however, significant that Landes' interpretation of what Weber had written in his essay is almost correct. ${ }^{42} \mathrm{~A}$ couple of years later he was followed by Niall Ferguson, in a much more confused discussion of the impact of the Protestant ethic in his The Cash Nexus (2001). 'The idea persists that Christian culture is at once more friendly to capitalism and more hostile to despotism than the religious cultures of Asia.' ${ }^{43}$

Although my examples are few, it seems, however, that at least some economic historians are gradually giving up their former critical attitude towards the Weber Thesis. At the same time sociologists, taking notice of the more nuanced discussions of Weber's original essay and following more keenly the recent German interpretations of Weber's thinking, find it no longer easy to condense Weber's ideas to its formerly clichéd form.

\section{Conclusion}

The Weber Thesis has had an interesting history as the established interpretation of the famous essay which was originally published in 1904-1905 in German. The first English translation was only published 25 years later in 1930, and it unfortunately gave support for

41. David S. Landes, The Wealth and Poverty of Nations: Why Some Are So Rich and Some So Poor (New York: Little, Brown \& company, 1998), p. xxx.

42. Landes, Wealth and Poverty, pp. 174-75. Landes states that what was important for Weber in Puritanism was the 'defining and sanctioning an ethic of everyday behaviour'. Landes, however, believes that Weber gave this process as a cause 'promoting the rise of modern capitalism', as in actual fact Weber only saw it as, possibly, giving a boost to an already existing capitalist economic order.

43. Niall Ferguson, The Cash Nexus: Money and Power in the Modern World 17002000 (London: Allen Lane, 2001), p. 366. In this context Ferguson refers to the study made by Robert J. Barro, Determinants of Economic Growth: A Cross-Country Empirical Study (Cambridge, MA: The MIT Press, 1997). Ferguson's confusion concerning the Weber Thesis becomes visible when reading his endnotes, where he lists some traditional arguments against it. Ferguson, Cash Nexus, p. 481. 
the contemporary German reception of the essay which only took seriously its emphasis on the role of Calvinism and neglected other original aspects of Weber's text. In addition, several influential readers of Weber Protestant Ethic essay have contributed to the peculiar strength of the misinterpretation of his original views. ${ }^{44}$ The first reliable English translation of the essay came in 2002. So it is only natural that what other people said and wrote about the Protestant Ethic essay has always been important for its understanding, especially outside Germany. Among these others, economic historians have fulfilled a special role, that of a critical voice reminding other social scientists that the Weber Thesis is a glaringly mistaken description of what actually happened in European economic history. Many economic historians were also proud to be able to correct what they thought to be an elementary mistake made by a famous scholar.

Sociologists have defended Weber against this obvious truth by claims that, in the end, when the big picture is taken into account, the Weber Thesis is somehow, at least partially right or, anyway, interesting and fruitful as a hypothesis to be used for theoretical purposes. The legitimating role of the Protestant Ethic essay has been obvious after the Second World War. Especially the version of the modernization theory needed the support of the good reputation of a master sociologist. Indeed, especially important was that Weber was thought to have proved that historical materialism was inadequate or even wrong. During this period, the attitudes of sociologists and historians were quite distant from one another.

Economic historians were, of course, on the right track in criticizing the Weber Thesis. What is surprising is that they usually did not advance a couple of steps further and notice that the Weber Thesis was not actually Weber's thesis. So, even when criticizing the Weber Thesis, they at the same time promoted it and made it even more plausible, especially to those who very easily concluded that the historian's point of view is necessarily too narrow. ${ }^{45}$ Other

44. See, for example, Green, Weber Thesis and its Critics (1959); M.J. Kitch (ed.), Capitalism and Reformation: Problems and Perspectives in History (London: Longman, 1967); Philippe Besaard (ed.), Protestantisme et capitalisme: La controverse post-weberienne (Paris: Colin, 1970); Green, Protestantism, Capitalism, and the Social Sciences (a revised edition of Green, 1959); S.N. Eisenstadt (ed.), The Protestant Ethic and Modernization: A Comparative View (New York: Basic Books, 1968).

45. Talcott Parson's new preface to his translation of the Protestant Ethic essay (the 1958 edition) criticizes those who concentrate on 'specific historical questions' instead of the wonderful theoretical or methodological example that Weber presents 
social scientists did not want to take historians seriously, and historians have paid, at least in this case, too much respect for the opinions of social scientists. ${ }^{46}$

to us. What this example gives us remains clouded in Parson's eloquent but obscure description of Weber's contribution. 'Weber was able to place the role of values in the determination of human social action in a theoretical light which made the older versions of the problem definitely obsolete.' Talcott Parsons, 'Preface to New Edition', in Max Weber, The Protestant Ethic and the Spirit of Capitalism (Mineola and New York: Dover Publications, 2003 [1958]), p. xvi.

46. Recently there has emerged a significant difference between AngloAmerican and German interpretations of the Protestant Ethic essay, where German opinions have more or less given up the Weber Thesis interpretation of it. Compare, for instance William H. Swatos Jr and Lutz Kaelber (eds.), The Protestant Ethic Turns 100: Essays on the Centenary of the Weber Thesis (Boulder: Paradigm, 2005) and Wolfgang Schluchter and Friedrich Wilhelm Graf (eds.), Asketischer Protestantismus und der 'Geist' des modernen Kapitalismus (Tübingen: Mohr Siebeck, 2005). 